\title{
Probiotic fermented beverages based on acid whey
}

\author{
Katarzyna Skryplonek, ${ }^{*}$ Izabela Dmytrów, and Anna Mituniewicz-Małek \\ Department of Dairy Technology and Food Storage, Faculty of Food Sciences and Fisheries, West Pomeranian University of Technology, \\ Papieża Pawła VI Str. 3, 71-459 Szczecin, Poland
}

\section{ABSTRACT}

Acid whey is a byproduct of cheesemaking that is difficult to use because of its low $\mathrm{pH}$ and less-favorable processing properties compared with rennet whey. The aim of this study was to evaluate the qualities of fermented beverages made using acid whey. In manufacturing the beverages, we used probiotic cultures Lactobacillus acidophilus LA-5 or Bifidobacterium animalis ssp. lactis BB-12. The production process included combining pasteurized acid whey with UHT milk, unsweetened condensed milk, or skim milk powder. We introduced milk to enrich casein content and obtain a product with characteristics similar to that of fermented milk drinks. The products were stored under refrigerated conditions $\left(5 \pm 1^{\circ} \mathrm{C}\right)$ for $21 \mathrm{~d}$. During storage, we assessed the beverages' physicochemical properties and organoleptic characteristics. The properties of the beverages depended on their composition, microbial culture, and storage time. Beverages containing L. acidophilus had higher acidity, which increased during storage; the acidity of samples containing $B$. animalis was more stable. Beverages made with skim milk powder (La1 and Bb1) had higher acetaldehyde content, but this parameter decreased in all samples during storage. The hardness of the samples did not change during storage and was highest in beverage La3, made from whey, condensed milk, and L. acidophilus. Beverage La2, made from whey, milk, condensed milk, and L. acidophilus, had the best sensory properties. The whey beverages we developed provided a good medium for the probiotic bacteria; bacteria count throughout the storage period exceeded $8 \log \mathrm{cfu} / \mathrm{mL}$, distinctly higher than the minimum therapeutic dose.

Key words: acid whey, fermented beverage, Lactobacillus acidophilus LA-5, Bifidobacterium animalis ssp. lactis BB-12

Received January 28, 2019.

Accepted May 14, 2019.

*Corresponding author: katarzyna.skryplonek@zut.edu.pl

\section{INTRODUCTION}

A main byproduct of the dairy industry is whey from cheese or casein production. Because about a third of total milk production is used to make cheese, and during cheesemaking whey is about 85 to $90 \%$ of milk volume, a great deal of whey is produced - about $19 \times$ $10^{6}$ t per year (Pereira et al., 2015). Whey is a yellowgreenish liquid that contains about $50 \%$ milk solids, including lactose, whey proteins, and mineral compounds. The fat content of whey is low, and the casein content, which forms the cheese curd, is negligible. The total solid content in whey is about $6.7 \%$ (FAO, 2013). Depending on the type of milk coagulation, there are 2 types of whey: rennet whey, which remains after enzymatic milk coagulation, and acid whey, a byproduct of milk coagulation by acidification. The presence of lactic acid, a distinctly lower $\mathrm{pH}$, and a higher concentration of minerals makes acid whey less suitable for processing than its rennet equivalent; its management is problematic, especially for small dairy industries.

Although whey is a byproduct, whey ingredients have a wide range of nutritional and health-promoting properties. A growing body of literature indicates that the properties of whey and whey proteins include antioxidant activity; antimicrobial, immune-stimulating, and anticancer features; reduction of blood pressure and the risk of cardiovascular disease and osteoporosis; and satiety regulation (Ha and Zemel, 2003; Kassem, 2015; Khan et al., 2015).

Given its valuable nutritional characteristics and growing consumer awareness of the effects of diet on health and well-being, a range of new food products have been developed based on whey. Unprocessed whey is not attractive to consumers because of its sensory properties, but it is used as a food ingredient. Because it is liquid, it seems natural to use it as a raw material for the production of unfermented and fermented beverages (Jeličić et al., 2008; Chavan et al., 2015). Whey has proven to be a good medium for the growth of yogurt bacteria (Kar and Misra, 1999; GallardoEscamilla et al., 2005; Pescuma et al., 2010), kefir grains (Athanasiadis et al., 2004; Koutinas et al., 2007; Magalhães et al., 2010, 2011), and probiotic bacteria 
from the Lactobacillus and Bifidobacterium genera (Drgalić et al., 2005; Hernandez-Mendoza et al., 2007; Almeida et al., 2008; Burns et al., 2008; Zoellner et al., 2009; Castro et al., 2013; Shukla et al., 2013; Bulatović et al., 2014a). Adding probiotic bacteria to whey can enhance its nutritional benefits, making it a functional food. Probiotic dairy products are significant group of functional foods whose global market has increased in recent years (Granato et al., 2010; Turkmen et al., 2019). Whey ingredients not only stimulate the growth and survival of probiotic bacteria (de Castro et al., 2009; Bulatović et al., 2014b), but also improve the viability of lactic acid bacteria in the gastrointestinal tract (Kar and Misra, 1999). Moreover, probiotic whey beverages stimulate the immune system, reduce blood pressure and serum cholesterol levels, and reduce the risk of cancer (Hernandez-Mendoza et al., 2007; Shah, 2007). As well as its health-promoting properties, whey fermentation leads to other advantages, such as a decrease in lactose content, partial hydrolysis of whey protein (which may cause allergies), increase in shelf life because of lactic acid, and production of aroma compounds that improve sensory features (Pescuma et al., 2010; Chavan et al., 2015). The disadvantage of using whey for fermented beverage production is its low solid and casein content, giving whey products a watery consistency. To improve textural characteristics, whey can be combined with fresh milk, condensed milk, or milk powder.

We performed this study to evaluate the possibility of obtaining high-quality probiotic beverages using acid whey. To this aim, we assessed the physicochemical and sensory characteristics of fermented beverages based on acid whey combined with milk, condensed milk, or skim milk powder and containing Lactobacillus acidophilus LA-5 or Bifidobacterium animalis ssp. lactis BB-12. We evaluated the quality of the products over 3 wk under refrigerated storage conditions.

\section{MATERIALS AND METHODS}

\section{Materials}

Tested beverages were prepared from acid whey that originated from semifat quark cheese production, which came from the dairy industry in northwest Poland. The quark cheese was made from pasteurized cow milk with approximately $0.8 \%$ fat and was coagulated by acidification, using a lactic acid bacteria starter culture. The obtained whey was cooled to $5 \pm 2^{\circ} \mathrm{C}$, transported to the laboratory, and used for beverage production. The beverages were made on the day of whey production. Auxiliary raw materials used in beverage production were pasteurized milk with $3.2 \%$ fat and $3.2 \%$ protein; condensed unsweetened UHT milk with $7.5 \%$ fat, $6.6 \%$ protein, and $17.5 \%$ nonfat milk solids; and skim milk powder, with $0.2 \%$ fat, $35 \%$ protein, and $96 \%$ total solids (all from SM Gostyń, Poland). Fermentation of the prepared formulations was carried out using probiotic bacteria starter cultures L. acidophilus LA-5 or B. animalis ssp. lactis BB-12 (both from Chr. Hansen, Hørsholm, Denmark).

The acid whey was submitted to thermal treatment at $72^{\circ} \mathrm{C}$ for $10 \mathrm{~min}$ and cooled to approximately $20^{\circ} \mathrm{C}$. In a preliminary study we found that thermal treatment enabled us to reduce the total bacteria count from $7 \log$ to $1 \log \mathrm{cfu} / \mathrm{mL}$ (data not shown). Then, we mixed the whey with milk, condensed milk, or skim milk powder. The proportion of whey and milk types is shown in Table 1 . The mixtures were heated to $42^{\circ} \mathrm{C}$ and inoculated with $0.6 \mathrm{~g} / \mathrm{L}$ of direct vat set starter cultures of L. acidophilus LA-5 (beverages La1, La2, and La3) or B. animalis ssp. lactis BB-12 (beverages $\mathrm{Bb} 1, \mathrm{Bb} 2$ and $\mathrm{Bb} 3)$. The mixtures were poured into low-density polyethylene cups (50 mL capacity), tightly covered with aluminum foil, and incubated at $42 \pm$ $1^{\circ} \mathrm{C}$ for $7.5 \mathrm{~h}$ (beverages with L. acidophilus) or $6.5 \mathrm{~h}$ (beverages with $B$. animalis ssp. lactis) until a firm curd was obtained. We adjusted the temperature of fermentation according to the results of the preliminary study. Although the optimal temperature for Bifidobacterium spp. is 37 to $41^{\circ} \mathrm{C}$ and for L. acidophilus is 35 to $40^{\circ} \mathrm{C}$, these bacteria have been shown to grow in temperatures up to $45^{\circ} \mathrm{C}$ (Gomes and Malcata, 1999). Choosing a temperature of $42^{\circ} \mathrm{C}$ enabled us to reduce fermentation time and the titratable acidity of the final product (data not shown); the same conclusion was drawn by Bulatović et al. (2014a). The beverages were then cooled and stored at refrigerated conditions ( $5 \pm$ $1^{\circ} \mathrm{C}$ ) for 3 wk. Analyses were carried out after 1, 4, 7, 14 , and $21 \mathrm{~d}$.

\section{Methods}

Whey Analysis. The following physicochemical characteristics of the whey were tested: $\mathrm{pH}$, using a $\mathrm{pH}$ meter (CP-411; Elmetron, Zabrze, Poland); titratable acidity as percent of lactic acid by titration with 0.25 $M \mathrm{NaOH}$ solution; total solids content by drying at $102^{\circ} \mathrm{C}$; density using a lactodensimeter (PKN, 1996) and total protein content using the Kjeldahl method (PKN, 2014).

Beverage Analysis. We evaluated the following physicochemical properties of the beverages: $\mathrm{pH}$, using a pH meter (CP-411, Elmetron); titratable acidity as percent of lactic acid (AOAC International, 1997); total solids content by drying at $130^{\circ} \mathrm{C}$ (AOAC International, 1997); and acetaldehyde content as one of the main 
Table 1. Composition of probiotic fermented beverages based on acid whey

\begin{tabular}{|c|c|c|c|c|c|}
\hline \multirow[b]{2}{*}{ Beverage } & \multicolumn{3}{|c|}{ Main ingredients (\%; wt/wt) } & \multirow{2}{*}{$\begin{array}{c}\text { Skim milk } \\
\text { powder } \\
(\mathrm{g} / 100 \mathrm{~g})\end{array}$} & \multirow[b]{2}{*}{ Probiotic culture } \\
\hline & Whey & Milk & $\begin{array}{l}\text { Condensed } \\
\text { milk }\end{array}$ & & \\
\hline La1 & 50 & 50 & 0 & 5 & Lactobacillus acidophilus LA-5 \\
\hline Bb1 & 50 & 50 & 0 & 5 & Bifidobacterium animalis ssp. lactis $\mathrm{BB}-12$ \\
\hline $\mathrm{La} 2$ & 50 & 25 & 25 & - & Lactobacillus acidophilus LA-5 \\
\hline $\mathrm{Bb} 2$ & 50 & 25 & 25 & - & Bifidobacterium animalis ssp. lactis BB-12 \\
\hline La3 & 50 & 0 & 50 & - & Lactobacillus acidophilus LA-5 \\
\hline Bb3 & 50 & 0 & 50 & - & Bifidobacterium animalis ssp. lactis BB-12 \\
\hline
\end{tabular}

aroma compounds, using a diffusive method (Lees and Jago, 1969). The study included also a texture profile analysis, which we performed using the texture analyzer TA.XT plus (Stable Micro Systems, Godalming, UK). The samples were penetrated with a cylindrical aluminum probe (20 $\mathrm{mm}$ diameter) with a trigger force of 1 $g$, a penetration distance of $25 \mathrm{~mm}$, and a test speed of $5 \mathrm{~m} / \mathrm{s}$. According to Salvador and Fiszman (2004) and Damin et al. (2009), a crucial parameter of the textural characteristics of fermented milk beverages is hardness. For this reason, we limited our analysis to this parameter. Sensory analysis was performed by panel of 6 trained evaluators using a 5-point hedonic scale and included assessment of appearance, consistency, taste, and flavor. The scale ranged from 1 (very poor quality) to 5 (very good quality). We used the mean scores for each attribute to calculate overall sensory quality - a weighted average of the scores, where the weights reflected the influence of each factor on determination of overall product quality. Taste had weight of 0.30 , flavor of 0.30 , consistency of 0.25 , and appearance of 0.15 . The conditions for the sensory analysis were in accordance with international guidelines (PKN, 1998).

To determine viable probiotic bacteria count, we carried out microbiological analysis. We prepared dilutions of the tested beverages using buffered peptone water (BTL, Warsaw, Poland) and enumerated selected dilutions using the pour-plate method on MRS agar medium (BTL). Plates with both bacteria cultures were kept at $37^{\circ} \mathrm{C}$ for $72 \mathrm{~h}$. The L. acidophilus strain was kept in microaerophilic conditions, but $B$. animalis required anaerobic conditions (Drgalić et al., 2005). We limited the study to probiotic bacteria analysis. We did not test the overall microbial quality of the products, because they were made of heat-treated ingredients; following good manufacturing practices should have ensured the safety of the products.

\section{Statistical Analysis}

The analyses were conducted in 3 or 5 (hardness) replicates and calculated mean and standard deviation.
We used Statistica StatSoft software (StatSoft Inc., Tulsa, OK) for statistical analysis and set the significance level at $P<0.05$. We compared the mean values of the beverage quality properties using Tukey's HSD test and evaluated the influence of composition and storage time on beverage characteristics using ANOVA.

\section{RESULTS AND DISCUSSION}

The physicochemical properties of the acid whey we used as a raw material are presented in Table 2. These characteristics were typical for acid whey (FAO, 2013), and its sensory properties were positively assessed. The whey had a fresh and intensive flavor, and a yellowgreenish opaque color. It was assessed as a high-quality raw material for the production of fermented probiotic beverages.

The results of 2-way ANOVA are presented in Table 3 , and the physicochemical properties of the wheybased fermented beverages during 3 wk of refrigerated storage are shown in Table 4.

Whey ensures good conditions for the growth of probiotic bacteria (Pescuma et al., 2008; Castro et. al., 2013; Bulatović et al., 2014a). Whey proteins contain considerable amounts of sulfur amino acids, which are released during heat treatment and protect probiotic bacteria against oxidative stress (Akalin et al., 2007). Moreover, due to their buffering capacity, whey proteins stabilize $\mathrm{pH}$, contributing to better bacteria survivability (Pescuma et al., 2010). Nevertheless, to obtain a product with sensory properties similar to fermented milk, milk must be added to the whey. The addition of milk increases the amount of casein, which is present in

Table 2. Characteristics of the whey used in beverage production ${ }^{1}$

\begin{tabular}{lc}
\hline Characteristic & Value \\
\hline Total solids (\%) & $6.48 \pm 0.11$ \\
Protein (\%) & $1.02 \pm 0.15$ \\
Density (g/mL) & $1.025 \pm 0.000$ \\
Titratable acidity (\% lactic acid) & $0.49 \pm 0.00$ \\
pH & $4.85 \pm 0.01$ \\
\hline
\end{tabular}

${ }^{1}$ Results are presented as mean $\pm \mathrm{SD}$. 
whey only in trace amounts. Casein forms the structure of fermented beverages and increases their viscosity (Damin et al., 2009; Marafon et al., 2011). The results of preliminary studies (data not shown) showed that good sensory quality may be achieved by combining acid whey with milk and skim milk powder, milk and condensed milk, or only condensed milk. These products have properties similar to popular fermented milk drinks, such as yogurt. Other authors have combined whey with milk in the production of fermented drinks (de Castro et al., 2009; Castro et al., 2013; Bulatović et al., 2014a), but they investigated beverages made from rennet whey.

Hardness is a crucial factor of the texture of dairy products. Our results showed that hardness was the only parameter influenced entirely by the composition of the beverage, not by storage time (Table 3 and Table 4). The hardness of products containing L. acidophilus was similar that of products containing $B$. animalis ssp. lactis, but the products containing condensed milk had significantly lower hardness when they were fermented with the latter culture. The highest hardness value during the entire storage period was for beverage La3, which contained the L. acidophilus strain and condensed milk. The hardness of this product ranged from 0.148 to $0.176 \mathrm{~N}$. Hardness values for the other beverage variants were similar.

Other quality parameters - acetaldehyde content, titratable acidity, $\mathrm{pH}$, total solids content, and bacteria count, as well as overall sensory quality - were influenced by the type of product and the storage time (Table 3).
Acetaldehyde is a crucial component of the aroma of fermented milk drinks, and its concentration contributes to the sensory quality of the product (Beshkova et al., 1998). This aroma compound is synthesized from lactose or the amino acid threonine. Both of these components are present in whey, and as stated by Magalhães et al. (2011), the production of acetaldehyde in whey may be as intensive as in milk. The acetaldehyde content in the products we created was low, from 0.318 to $1.668 \mathrm{mg} / \mathrm{kg}$, and was higher in beverages containing $B$. animalis ssp. lactis, than in those containing $L$. acidophilus (Table 4). Low levels of acetaldehyde may be explained by the fact that unlike yogurt bacteria, probiotics do not have the typical capacity to synthesize it (Beshkova et al., 1998). The low acetaldehyde content in probiotic products may be connected with their long fermentation time, leading to the degradation of this aroma compound to ethanol and acetonine (Zaręba et al., 2008). Products containing skim milk powder (La1 and Bb1) were had higher acetaldehyde content than products containing condensed milk (La2, Bb2, La3, Bb3). During storage, we noted a decrease in acetaldehyde content; this is typical for fermented milk products and is due to the high volatility of this component (Beshkova et al., 1998; Guven et al., 2005).

Titratable acidity, measured as the lactic acid content, was distinctly higher in beverages containing $L$. acidophilus than in beverages containing $B$. animalis ssp. lactis (Table 4), indicating better fermentation ability for the former strain. Comparing the beginning and the end of the storage time, we found that the titratable acidity was slightly higher at the end of

Table 3. Physicochemical properties, bacteria count, and overall sensory quality of probiotic fermented beverages based on acid whey: 2-way ANOVA

\begin{tabular}{llrrr}
\hline Indicator & Factor & $F$-value & $P$-value & $F$ test \\
\hline Hardness & Time of storage & 1.100 & 0.361 & 2.463 \\
& Type of beverage & 25.038 & $<0.001$ & 2.463 \\
\multirow{3}{*}{ Acetaldehyde content } & Interactions & 0.981 & 0.483 & 1.746 \\
& Time of storage & 36.162 & $<0.001$ & 2.557 \\
Titratable acidity & Type of beverage & 855.533 & $<0.001$ & 2.557 \\
& Interactions & 12.397 & $<0.001$ & 1.850 \\
& Time of storage & 404.047 & $<0.001$ & 2.557 \\
pH & Type of beverage & $10,432.477$ & $<0.001$ & 2.557 \\
& Interactions & 50.500 & $<0.001$ & 1.850 \\
Total solids & Time of storage & $2,218.438$ & $<0.001$ & 2.557 \\
& Type of beverage & $4,487.734$ & $<0.001$ & 2.557 \\
Bacteria count & Interactions & 72.041 & $<0.001$ & 1.850 \\
& Time of storage & 14.172 & $<0.001$ & 2.557 \\
Overall sensory quality & Type of beverage & 852.332 & $<0.001$ & 2.557 \\
& Interactions & 1.670 & 0.084 & 1.850 \\
& Time of storage & 31.327 & $<0.001$ & 2.557 \\
& Type of beverage & 193.897 & $<0.001$ & 2.557 \\
& Interactions & 13.488 & $<0.001$ & 1.850 \\
& Time of storage & 9.560 & $<0.001$ & 2.557 \\
& Type of beverage & 412.269 & $<0.001$ & 2.557 \\
& Interactions & 22.811 & $<0.001$ & 1.850 \\
\hline
\end{tabular}

*Significant difference at $P<0.05$. 
Table 4. Characteristics of probiotic fermented beverages based on acid whey during refrigerated storage ${ }^{1}$

Time of storage (d)

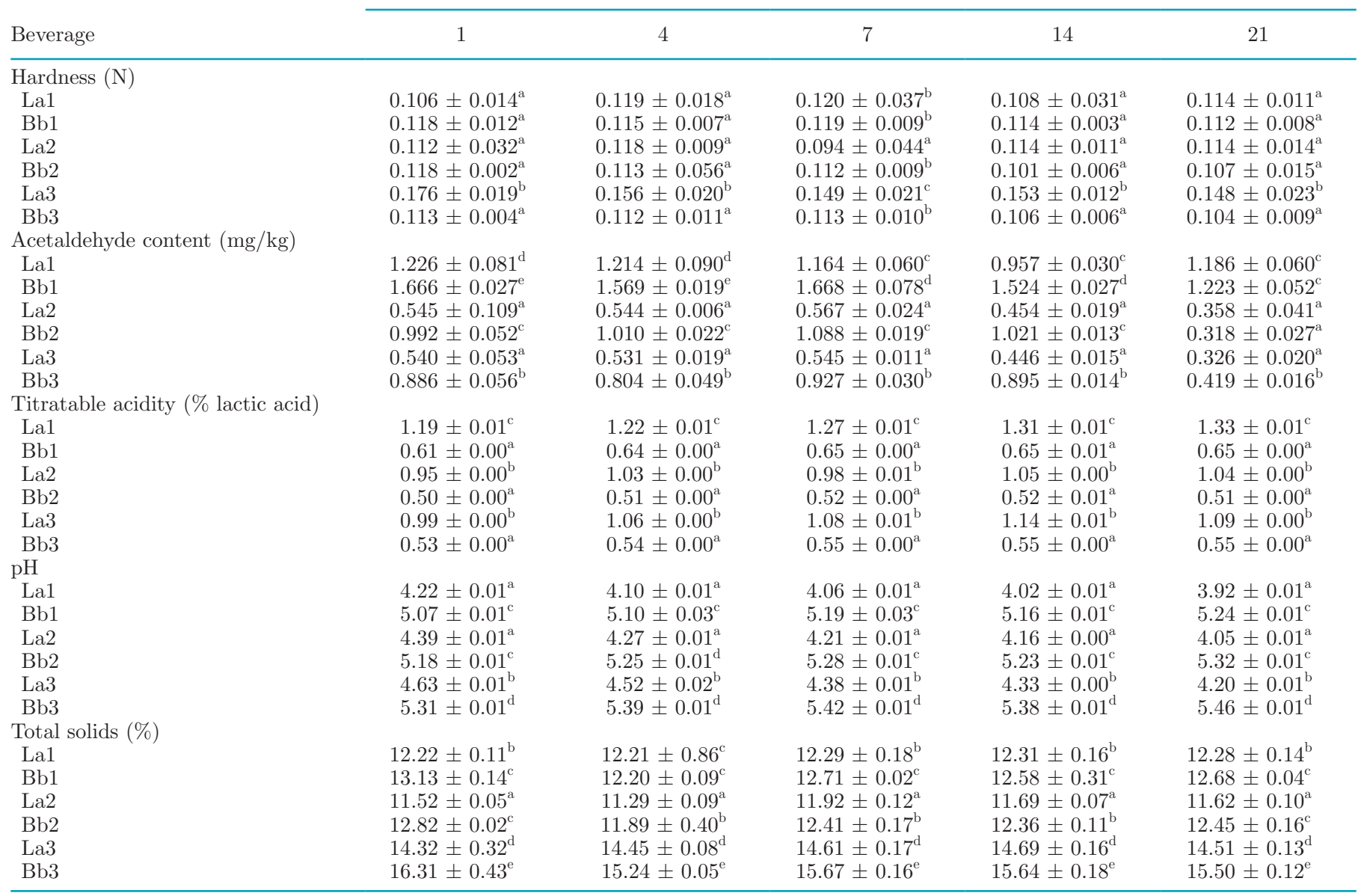

${ }^{\mathrm{a} e}$ Means within columns with different superscript letters differ; $P<0.05$.

${ }^{1}$ Results are presented as mean $\pm \mathrm{SD}$.

storage, but values fluctuated over time. The acidity of the $\mathrm{Bb}$ beverages was more stable than that of the La beverages. Similar to lactic acid content, beverages containing L. acidophilus had a lower $\mathrm{pH}$. Moreover, beverages containing skim milk powder (La1 and Bb1) were more acid than the other variants. This finding may lead to the conclusion that the addition of skim milk powder enhanced the activity of the tested probiotic bacteria. The $\mathrm{pH}$ of beverages containing $L$. acidophilus decreased constantly over storage, and the $\mathrm{pH}$ of beverages containing $B$. animalis ssp. lactis had their highest $\mathrm{pH}$ values at the end of storage period. A similar tendency was observed by Drgalić et al. (2005) in probiotic fermented beverages from rennet whey. Postacidification of fermented beverages during storage is a typical phenomenon caused by the activity of the bacteria, which can conduct lactic acid fermentation even in refrigerated temperatures (Antunes et al., 2005). The lack of postacidification we observed in products containing B. animalis ssp. lactis indicates poor activity of this bacteria, although the decrease in $\mathrm{pH}$ is undesirable in probiotic products because of its inhibitory effect on vulnerable probiotic bacteria (de Castro et al., 2009). Moreover, postacidification decreases the sensory characteristics of products (de Castro et al., 2009).

We determined the total solids content by beverage composition and this parameter was highest in products made from whey combined with condensed milk (La3 and Bb3). Those products also had the highest $\mathrm{pH}$ value, a finding that may be explained by the high milk solids content, which has a buffering capacity (Pescuma et al., 2010). The ANOVA (Table 3) revealed that time also influenced solids content, connected with small fluctuations in this parameter over the storage period.

One of the most important factors when considering the quality of probiotic products is the count of viable cells of probiotic bacteria. The probiotic bacteria count 


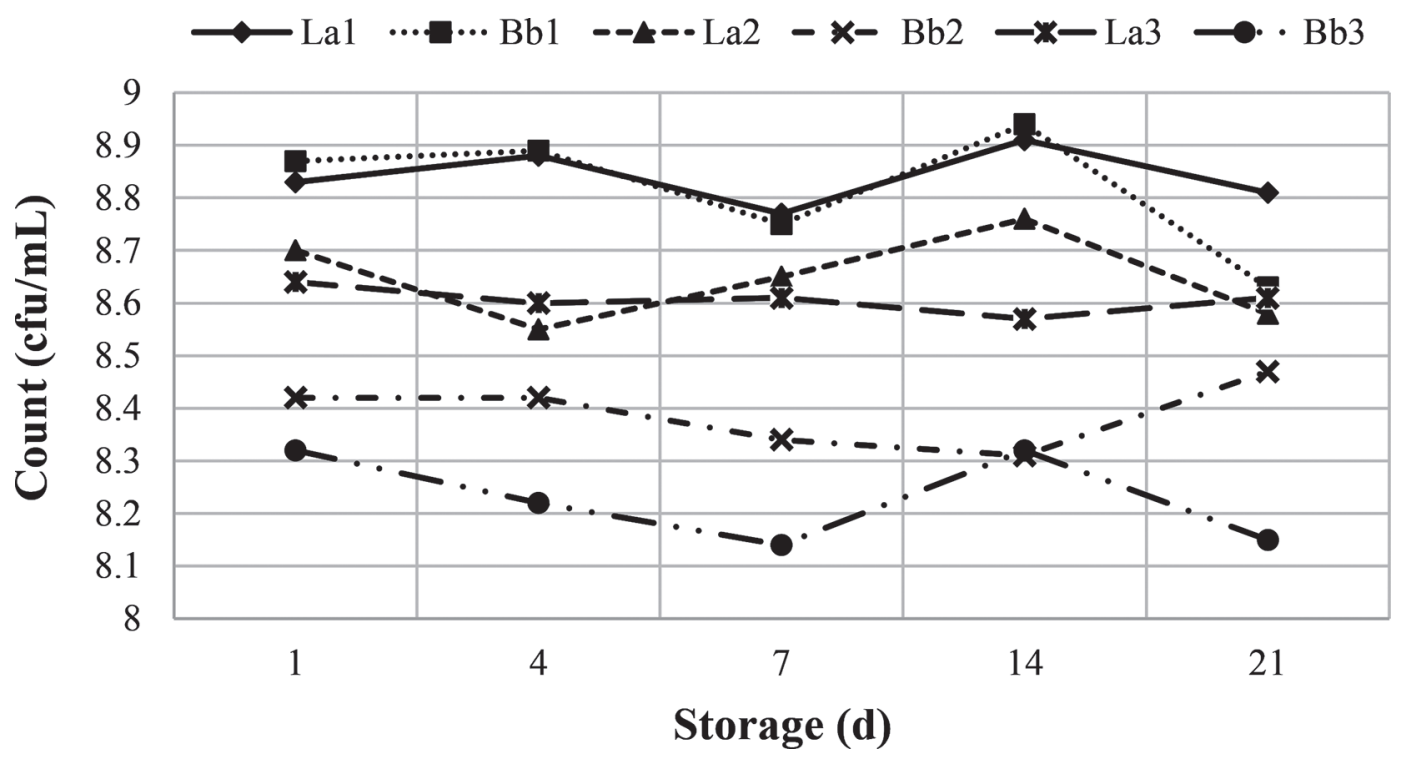

Figure 1. Counts of probiotic bacteria during refrigerated storage of fermented beverages based on acid whey. La1, La2, and La3 $=$ beverages with Lactobacillus acidophilus $\mathrm{LA}-5 ; \mathrm{Bb} 1, \mathrm{Bb} 2$, and $\mathrm{Bb} 3=$ beverages with Bifidobacterium animalis ssp. lactis $\mathrm{BB}-12$.

cannot be lower than $6 \mathrm{log} \mathrm{cfu} / \mathrm{mL}$ during storage, until the expiration date (Shah, 2007; Granato et al., 2010). The count of both strains of probiotic bacteria distinctly exceeded this required therapeutic dose, at the level of $8 \mathrm{log} \mathrm{cfu} / \mathrm{mL}$ (Figure 1) during the entire 3 -wk storage period. Bacteria count varied during storage, but remained at a high level.

Similar probiotic bacteria content was found by Drgalić et al. (2005), who obtained fermented whey with 7 to $8 \log \mathrm{cfu} / \mathrm{mL}$ of L. acidophilus LA-5 and 8 $\log \mathrm{cfu} / \mathrm{mL}$ of $B$. animalis ssp. lactis BB-12. In studies conducted by Almeida et al. (2008), the count of $B$. animalis in fermented whey was higher than that of $L$. acidophilus, at $8 \log$ and $6 \log \mathrm{cfu} / \mathrm{mL}$, respectively. A gradual decrease in the content of $L$. acidophilus and Bifidobacterium spp. bacteria in probiotic yogurts was confirmed by Kailasapathy et al. (2008). In the current study, the highest level of probiotics was observed in products containing skim milk powder (La1 and Bb1), which proved to be the best environment for tested bacteria. This fact may explain the higher acidity (both titratable and $\mathrm{pH}$ ) and higher acetaldehyde content in these products.

According to Castro et al. (2013), meeting the consumers' demands related to sensory properties is a crucial factor in achieving commercial success when launching a new product. Because we aimed to obtain beverages with sensory properties similar to typical fermented milk drinks such as yogurt, the ideal product needed to have a uniform and firm curd, minimal whey separation, a homogeneous and thick consistency, a clear and refreshing taste, and a flavor that combined the characteristics of whey and fermented milk. The results of the sensory assessment (overall sensory quality) are presented in Figure 2. In the products containing $L$. acidophilus, the variants with condensed milk had better sensory properties than variants with skim milk powder, because of the products with skim milk powder had a slightly less smooth consistency. However the sensory quality of the products containing B. animalis did not differ between samples. The consistency of the products containing L. acidophilus was creamier than those containing B. animalis. Products containing $B$. animalis had a less solid structure. The taste and flavor of the beverages was clear and refreshing; in products containing $B$. animalis, they were milder and less distinct. Drgalić et al. (2005) also compared fermented beverages containing L. acidophilus LA-5 and $B$. animalis BB-12 strains added to rennet whey. Similarly to our study, they found that products containing L. acidophilus had a more intense flavor. During storage, we observed a deterioration in sensory quality: syneresis started to occur, taste became more sour, and aroma became less intense.

\section{CONCLUSIONS}

The combination of acid whey, milk, condensed milk, and skim milk powder may be good raw material for the production of probiotic fermented beverages. The products, fermented using only 1 strain of probiotic bacteria (L. acidophilus LA-5 or B. animalis ssp. lactis BB-12) were characterized by high bacteria survivability and good quality properties. The quality 


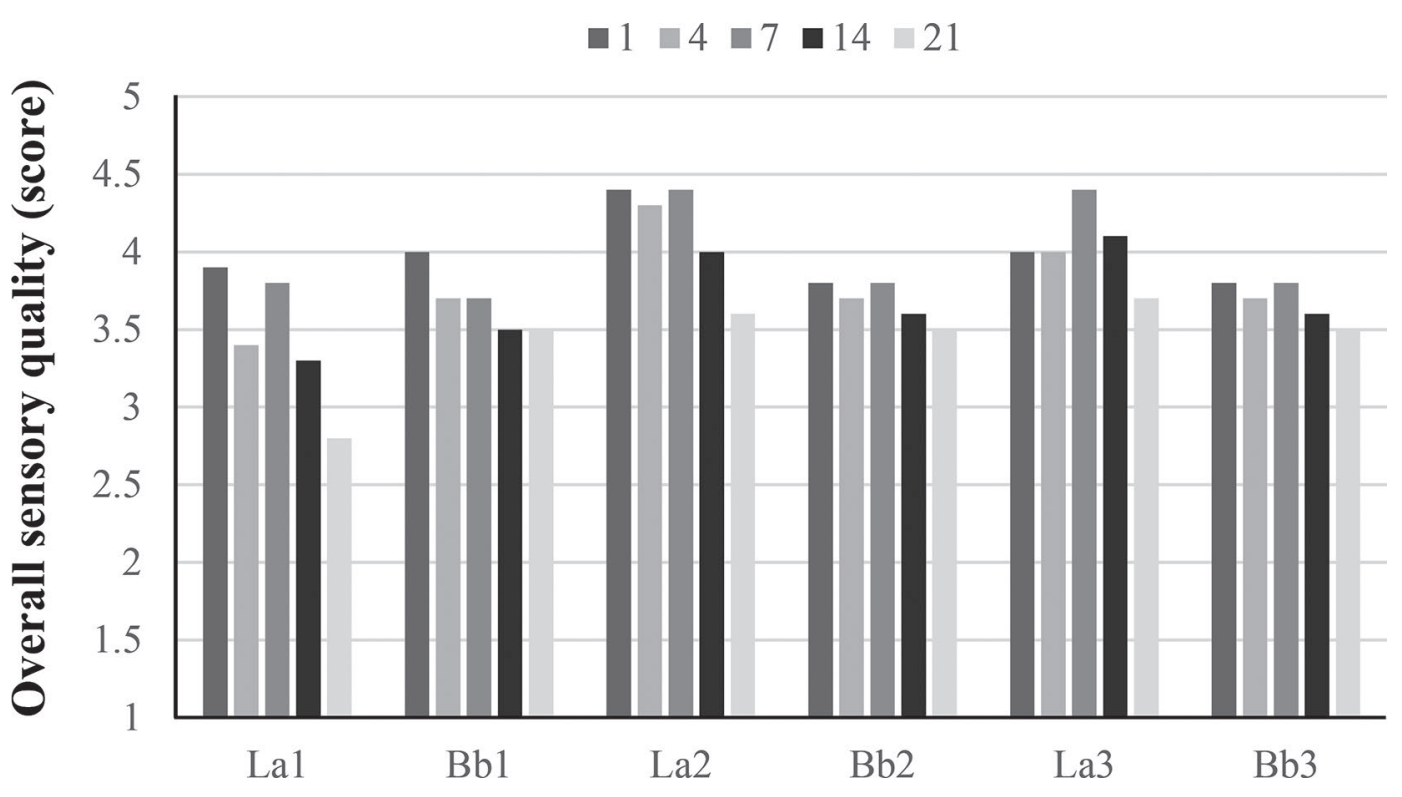

Figure 2. Overall sensory quality of probiotic fermented beverages based on acid whey during refrigerated storage (1, 4, 7, 14, or $21 \mathrm{~d})$. La1, $\mathrm{La} 2$, and $\mathrm{La} 3$ = beverages with Lactobacillus acidophilus $\mathrm{LA}-5$; Bb1, Bb2, and Bb3 = beverages with Bifidobacterium animalis ssp. lactis $\mathrm{BB}-12$.

properties and sensory characteristics of the products were influenced by composition, type of probiotic, and refrigerated storage time. The hardness of the samples did not change during storage time and was highest in beverage La3, which contained condensed milk and L. acidophilus. Beverages containing L. acidophilus had higher acidity, which increased during storage, but the acidity of samples containing $B$. animalis was more stable. Throughout the storage period, the probiotic bacteria count exceeded $8 \log \mathrm{cfu} / \mathrm{mL}$ and was highest in beverages containing skim milk powder (La1 and Bb1). These beverages were also characterized by higher acetaldehyde content, but this parameter decreased in all samples during storage. The best sensory properties were in beverage La2, made from whey, milk, condensed milk, and L. acidophilus. Consumers today are increasingly aware of the importance of a balanced diet to maintain health. Several studies have confirmed the excellent nutritional and health properties of whey, so it is a focus of food technologists' interests. The great potential of whey can be increased by using it to produce functional probiotic products. As well, the proposed application of fresh acid whey does not require complicated technological solutions and can be easily implemented by small dairy factories.

\section{ACKNOWLEDGMENTS}

This work was financed by research potential funds of Faculty of Food Sciences and Fisheries of West Pomeranian University of Technology.

\section{REFERENCES}

Akalin, A. S., S. Gönç, G. Ünal, and S. Fenderya. 2007. Effects of fructooligosaccharide and whey protein concentrate on the viability of starter culture in reduced-fat probiotic yogurt during storage. J. Food Sci. 72:M222-M227. https://doi.org/10.1111/j.1750-3841 2007.00436.x.

Almeida, K. E., A. Y. Tamime, and M. N. Oliveira. 2008. Acidification rates of probiotic bacteria in Minas frescal cheese whey. Lebensm. Wiss. Technol. 41:311-316. https://doi.org/10.1016/j.lwt.2007.02 .021 .

Antunes, A. E. C., T. F. Cazetto, and H. M. A. Bolini. 2005. Viability of probiotic micro-organisms during storage, postacidification and sensory analysis of fat-free yogurts with added whey protein concentrate. Int. J. Dairy Technol. 58:169-173. https://doi.org/10 .1111/j.1471-0307.2005.00203.x.

AOAC International. 1997. Official Methods of Analysis. 16th ed. AOAC International, Gaithersburg, MD.

Athanasiadis, I., A. Paraskevopoulou, G. Blekas, and V. Kiosseoglou. 2004. Development of a novel whey beverage by fermentation with kefir granules. Effect of various treatments. Biotechnol. Progr. 20:1091-1095. https://doi.org/10.1021/bp0343458.

Beshkova, D., E. Simova, G. Frengova, and Z. Simov. 1998. Production of flavour compounds by yogurt starter cultures. J. Ind. Microbiol. Biotechnol. 20:180-186. https://doi.org/10.1038/sj.jim.2900504.

Bulatović, M. L., T. Z. Krunić, M. Vukašinović Skulić, B. D. Zarić, and M. B. Rakin. 2014a. Quality attributes of a fermented wheybased beverage enriched with milk and a probiotic strain. RSC Advances 4:55503-55510. https://doi.org/10.1039/C4RA08905G.

Bulatović, M. L., M. B. Rakin, L. V. Mojović, S. B. Nikolić, M. S. Vukašinović Sekulić, and A. P. Đukić Vuković. 2014b. Improvement of production performance of functional fermented wheybased beverage. Chem. Ind. Chem. Eng. Q. 20:1-8. https://doi .org/10.2298/CICEQ120715096B.

Burns, P., G. Vinderola, F. Molinari, and J. Reinheimer. 2008. Suitability of whey and buttermilk for the growth and frozen storage of probiotic lactobacilli. Int. J. Dairy Technol. 61:156-164. https:/ /doi.org/10.1111/j.1471-0307.2008.00393.x.

Castro, W. F., A. G. Cruz, M. S. Bisinotto, L. M. R. Guerreiro, J. A. F. Faria, H. M. A. Bolini, R. L. Cunha, and R. Deliza. 2013. Development of probiotic dairy beverages: Rheological properties and 
application of mathematical models in sensory evaluation. J. Dairy Sci. 96:16-25. https://doi.org/10.3168/jds.2012-5590.

Chavan, R. S., R. C. Shraddha, A. Kumar, and T. Nalawade. 2015. Whey based beverage: Its functionality, formulations, health benefits and applications. J. Food Process. Technol. 10:1-8. https:// doi.org/10.4172/2157-7110.1000495.

Damin, M. R., M. R. Alcântara, A. P. Nunes, and M. N. Oliveira. 2009. Effects of milk supplementation with skim milk powder, whey protein concentrate and sodium caseinate on acidification kinetics, rheological properties and structure of nonfat stirred yogurt. Lebensm. Wiss. Technol. 42:1744-1750. https://doi.org/10 $.1016 /$ j.lwt.2009.03.019.

de Castro, F. P., T. M. Cunha, P. J. Ogliari, R. F. Teófilo, M. M. C. Ferreira, and E. S. Prudêncio. 2009. Influence of different content of cheese whey and oligofructose on the properties of fermented lactic beverages: Study using response surface methodology. Lebensm. Wiss. Technol. 42:993-997. https://doi.org/10.1016/j.lwt .2008.12.010.

Drgalić, I., L. Tratnik, and R. Božanić. 2005. Growth and survival of probiotic bacteria in reconstituted whey. Lait 85:171-179. https:// doi.org/10.1051/lait:2005009.

FAO (Food and Agriculture Organization of the United Nations). 2013. Milk and Dairy Products in Human Nutrition. FAO Publications, Rome, Italy.

Gallardo-Escamilla, F. J., A. L. Kelly, and C. M. Delahunty. 2005. Influence of starter culture on flavor and headspace volatile profiles of fermented whey and whey produced from fermented milk. J. Dairy Sci. 88:3745-3753. https://doi.org/10.3168/jds.S0022 $-0302(05) 73060-5$.

Gomes, A. M. P., and F. X. Malcata. 1999. Bifidobacterium spp. and Lactobacillus acidophilus: Biological, biochemical, technological and therapeutical properties relevant for use as probiotics. Trends Food Sci. Technol. 10:139-157. https://doi.org/10.1016/S0924 -2244(99)00033-3.

Granato, D., G. F. Branco, A. Gomes Cruz, J. de Assis Fonseca Faria, and N. P. Shah. 2010. Probiotic dairy products as functional foods. Compr. Rev. Food Sci. Food Saf. 9:455-470. https://doi.org/10 $.1111 / \mathrm{j} .1541-4337.2010 .00120 . x$.

Guven, M., K. Yasar, O. B. Karaca, and A. A. Hayaloglu. 2005. The effect of inulin as a fat replacer on the quality of set-type low-fat yogurt manufacture. Int. J. Dairy Technol. 58:180-184. https://doi .org/10.1111/j.1471-0307.2005.00210.x.

Ha, E., and M. B. Zemel. 2003. Functional properties of whey, whey components, and essential amino acids: Mechanisms underlying health benefits for active people. J. Nutr. Biochem. 14:251-258. https://doi.org/10.1016/S0955-2863(03)00030-5. (Review).

Hernandez-Mendoza, A., V. J. Robles, J. O. Angulo, J. De La Cruz, and H. S. Garcia. 2007. Preparation of a whey-based probiotic product with Lactobacillus reuteri and Bifidobacterium bifidum. Food Technol. Biotechnol. 45:27-31.

Jeličić, I., R. Božanić, and L. Tratnik. 2008. Whey-based beveragesA new generation of dairy products. Mljekarstvo 58:257-274.

Kailasapathy, K., I. Harmstorf, and M. Philips. 2008. Survival of Lactobacillus acidophilus and Bifidobacterium animalis ssp. lactis in stirred fruit yogurts. Lebensm. Wiss. Technol. 41:1317-1322. https://doi.org/10.1016/j.lwt.2007.08.009.

Kar, T., and A. K. Misra. 1999. Therapeutic properties of whey used as fermented drink. Rev. Microbiol. 30:163-169. https://doi.org/10 .1590/S0001-37141999000200015.

Kassem, J. M. 2015. Future challenges of whey proteins. Int. J. Dairy Sci. 10:139-159. https://doi.org/10.3923/ijds.2015.139.159.

Khan, S., N. Amin, Z. Ansari, and D. R. Majumder. 2015. WHEY: Waste to health and wealth. Int. J. Curr. Microbiol. Appl. Sci. $2: 245-253$

Koutinas, A. A., I. Athanasiadis, A. Bekatorou, C. Psarianos, M Kanellaki, N. Agouridis, and G. Blekas. 2007. Kefir-yeast technology: Industrial scale-up of alcoholic fermentation of whey, promot- ed by raisin extracts, using kefir-yeast granular biomass. Enzyme Microb. Technol. 1:576-582. https://doi.org/10.1016/j.enzmictec 2007.05.013.

Lees, G. J., and G. R. Jago. 1969. Methods for the estimation of acetaldehyde in cultured dairy products. Aust. J. Dairy Technol. $24: 181-185$.

Magalhães, K. T., G. Dragone, G. de Melo Pereira, J. M. Oliveira, L. Domingues, J. A. Teixeira, J. B. Almeida e Silva, and R. F. Schwan. 2011. Comparative study of the biochemical changes and volatile compound formations during the production of novel whey-based beverages and traditional milk kefir. Food Chem. 126:249-253. https://doi.org/10.1016/j.foodchem.2010.11.012.

Magalhães, K. T., M. A. Pereira, A. Nicolau, G. Dragone, L. Domingues, J. A. Teixeira, J. B. de Almeida Silva, and R. F. Schwan. 2010. Production of fermented cheese whey-based beverage using kefir grains as starter culture: Evaluation of morphological and microbial variations. Bioresour. Technol. 101:8843-8850. https://doi.org/10.1016/j.biortech.2010.06.083.

Marafon, A. P., A. Sumi, M. R. Alcântara, A. Y. Tamime, and M. Nogueira de Oliveira. 2011. Optimization of the rheological properties of probiotic yoghurts supplemented with milk proteins. Lebensm. Wiss. Technol. 44:511-519. https://doi.org/10.1016/j.lwt .2010.09.005.

Pereira, C., M. Henriques, D. Gomes, A. Gomez-Zavaglia, and G. de Antoni. 2015. Novel functional whey-based drinks with great potential in the dairy industry. Food Technol. Biotechnol. 53:307314. https://doi.org/10.17113/ftb.53.03.15.4043.

Pescuma, M., E. M. Hébert, F. Mozzi, and G. Font de Valdez. 2008. Whey fermentation by thermophilic lactic acid bacteria: Evolution of carbohydrates and protein content. Food Microbiol. 25:442-451. https://doi.org/10.1016/j.fm.2008.01.007.

Pescuma, M., E. M. Hébert, F. Mozzi, and G. Font de Valdez. 2010. Functional fermented whey-based beverage using lactic acid bacteria. Int. J. Food Microbiol. 141:73-81. https://doi.org/10.1016/j .ijfoodmicro.2010.04.011.

PKN (Polish Committee for Standardization). 1996. Milk and Dairy Products. Whey. Test Methods. Polish Standard PN-A 86364:1996. PKN, Warsaw, Poland.

PKN (Polish Committee for Standardization). 1998. Sensory Analysis. Methodology. General Guidelines. Polish Standard PN-ISO 6658:1998. PKN, Warsaw, Poland.

PKN (Polish Committee for Standardization). 2014. Milk. Testing of Nitrogen Content. Part 1: Kjeldahl's Method. Polish Standard PN-EN ISO 8968-1. PKN, Warsaw, Poland. [In Polish].

Salvador, A., and S. M. Fiszman. 2004. Textural and sensory characteristics of whole and skimmed flavored set-type yogurt during long storage. J. Dairy Sci. 87:4033-4041. https://doi.org/10.3168/ jds.S0022-0302(04)73544-4.

Shah, N. P. 2007. Functional cultures and health benefits. Int. Dairy J. 17:1262-1277. https://doi.org/10.1016/j.idairyj.2007.01.014.

Shukla, M., J. Kumar, and S. Admassu. 2013. Development of probiotic beverage from whey and pineapple juice. J. Food Process. Technol. 4:1-4. https://doi.org/0.4172/2157-7110.1000206.

Turkmen, N., C. Akal, and B. Özer. 2019. Probiotic dairy-based beverages: A review. J. Funct. Foods 5:62-75. https://doi.org/10.1016/ j.jff.2018.12.004.

Zaręba, D., M. Obiedziński, and M. Ziarno. 2008. Porównanie profilu lotnych związków mleka fermentowanego i niefermentowanego przez bakterie jogurtowe i szczepy probiotyczne [Comparing the profile of volatile compounds in milk fermented and non-fermented by yoghurt bacteria and pro-biotic strains]. Żywność. Nauka. Technologia. Jakość. 3:18-32. (In Polish).

Zoellner, S. S., A. G. Cruz, J. A. F. Faria, H. M. A. Bolini, M. R. L. Moura, L. M. J. Carvalho, and A. S. Santana. 2009. Whey beverage with acai pulp as a food carrier of probiotic bacteria. Aust. J. Dairy Technol. 64:177-181. 